\title{
THE MANUSCRIPT OF WALT WHITMAN'S "SUNDAY EVENING LECTURES"
}

\author{
GARY WIHL
}

EDWARD F. GRIER's editorial note at the head of the text of "Sunday Evening Lectures" in Notebooks and Unpublished Prose Manuscripts states that the manuscript of the lectures is lacking. ${ }^{1}$ The following text of "Sunday Evening Lectures" is based on the bound manuscript in the Hanley Collection of Whitman materials at the Harry Ransom Center for Research in the Humanities, the University of Texas at Austin. ${ }^{2} \mathrm{Un}$ der the supervision of Edwin H. Miller, Harold Blodgett compiled an inventory of the Hanley Collection in 1955 but did not identify the manuscript of "Sunday Evening Lectures" as a distinct item. Somehow Grier and the other editors of The Collected Writings of Walt Whitman missed the manuscript when they produced Notebooks and Unpublished Prose Manuscripts. Joel Myerson also missed the manuscript in his Walt Whitman Archive. ${ }^{3}$ Kathryne V. Lindberg, in her 1991 essay on Whitman and Hegel, described the Hanley manuscript and used it, but it has remained unpublished. ${ }^{4}$

Grier's edition is based on the versions of the Lectures published by Richard Maurice Bucke in his Notes and Fragments Left By Walt Whitman (London, Ontario, 1899) and in volume six of The Complete Writings of Walt Whitman (New York: Putnam's Sons, 1902), which he edited with Thomas B. Harned and Horace L. Traubel. Bucke came into possession of the manuscript as one of Whitman's literary co-executors. As Bucke notes in his edition, the manuscript of "Sunday Evening Lectures" is fragmentary and incomplete. The connection and order of the fragments is open to interpretation, but the discussion of the German philosophers follows a basic chronology. Elbert Hubbard (1856-1915), the founder of the Roycroft Press and the experimental literary magazine The Philistine, acquired the manuscript from Bucke. T.E. Hanley then purchased the manuscript as a bound volume from Hubbard's library.

Hubbard admired Whitman and used to deliver his own Sunday evening lectures to his Roycrofters in East Aurora, New York. There is a good description of Hubbard's practice of lecturing and of his art of 
binding and printing in Albert Lane's Elbert Hubbard and His Work. ${ }^{5}$ Hubbard bound Whitman's manuscript into a single volume and included some memorabilia among the pages of manuscript. The ordering and connecting of the fragments in the bound manuscript differs significantly from Bucke's edition. The responsibility for the ordering of the manuscript fragments in the bound volume remains a mystery. Did Hubbard exercise his own judgment? Or did Bucke guide Hubbard? If so, why does the order differ so greatly from the edition that Bucke produced himself?

The correct ordering of the fragments is a matter of interpretation. But at the very least the ordering of the bound manuscript is more coherent and logical than the version that Bucke first published. The Bucke and Grier published texts reverse the order of the manuscript's discussion of Kant and Hegel. Bucke appears to have made a number of questionable editorial decisions, such as the placement of a fragment titled "Finale." "Finale" appears in the first half of the bound manuscript but becomes the conclusion in Bucke's version. Bucke molds several fragments of the manuscript into single paragraphs; these fragments appear in different combinations and orders within the Ransom Center manuscript. The endnotes attached to my transcription of the Ransom Center manuscript indicate the points where Bucke fuses independent fragments into single paragraphs. Bucke omits some fragments from the manuscript; Grier goes a step further and transfers out of the Lectures certain fragments that Bucke included.

Following are two transcriptions of the Ransom Center manuscript. In the first transcription, I have tried to capture some of the look of Whitman's writing on the page while still providing an accessible "reader's version" of the Lectures, leaving out all the false starts and other material that Whitman deleted, while incorporating his additions and insertions. Where a fragment is clearly a complete paragraph, I use an indentation. Otherwise the writing is reproduced as a block or, when Whitman's spacing seems idiosyncratic, line-by-line. I follow Whitman's anglicizing or italicizing of certain words and his use of the upper or lower case. The punctuation is not always grammatical, since the text was never revised for publication or finalized.

Following the reader's transcription, Ed Folsom and Matthew Miller offer a diplomatic textual transcription that indicates words, phrases, and sentences that Whitman deleted or inserted. Also noted in this transcription are the page breaks, fragment breaks, and extraneous inserted photographs and other materials. This version, while less "readable," gives us a sense of the significant revision evident in the manuscript. Whitman's insertion of material between or above lines is indicated by carets and by the bracketing of inserted material. Question-marks indicate words or parts of words that have been rendered illegible by Whitman's heavy strikeouts. 
Grier's notes to the Lectures trace a line of scholarship on the question of Whitman's knowledge of German idealist philosophy. The publication of this new version of "Sunday Evening Lectures" may direct new attention to Whitman's understanding of German idealism in relation to the development of his own notions of the poetic self and the democratic individual. In a recent essay, Richard Rorty accounts for Whitman's humanism and political optimism on the basis of Hegel's influence. ${ }^{6}$ If Rorty's claim is valid, we are likely to understand that influence better by coming closer to Whitman's actual commentary on the writings of Hegel, Kant, Fichte and Schelling in the Sunday Evening Lectures.

Emory University

\section{NOTES}

1 Notebooks and Unpublished Prose Manuscripts (New York University Press, 1984), 6:2009. Abbreviated in the following notes as NUPM.

2 I wish to express my thanks to the Harry Ransom Center for Research in the Humanities for the award of a Mellon Research Fellowship, which enabled me to examine their collection of Whitman manuscripts, and for permission to produce this transcript of the manuscript of "Sunday Evening Lectures." I am greatly indebted to John Kirkpatrick, curator of British Manuscripts, who brought the manuscript to my attention in the first place and for his assistance in completing some final checks of my transcript. I also thank the Department of Rare Books and Manuscripts at the Perkins Library, Duke University, for making available to me their copies of Bucke's Notes and Fragments. I'm grateful to Ed Folsom for his editorial guidance in the preparation of this transcription.

3 See The Walt Whitman Archive (New York: Garland, 1993), Vol. 2 (Whitman Manuscripts at Duke University and the Humanities Research Center of the Univeristy of Texas).

4 "Whitman's 'Convertible Terms': America, Self, Ideology," in Theorizing American Literature: Hegel, the Sign, and History, ed. Bainard Cowan and Joseph G. Kronick (Baton Rouge: Louisiana State University Press, 1991), 223-268.

5 Worcester, MA: The Blanchard Press, 1901.

6 See Rorty's Achieving Our Country (Cambridge MA: Harvard University Press, 1998). 


\title{
[Reader's Transcription by Gary Wihl]
}

\author{
Sunday \\ used 2 March '99' \\ evening \\ $\underline{\text { Lectures }}$
}

Kant 1724 to 1804

Fichte 1762 to 1814

Schelling 1775 to 1854

died in Switzerland

Hegel 1770 to 1831

Enc. Brit. Vol. 13. p. 46

I. K.

moral portrait of him by

Herder, 1795.

"I have had the good fortune to know a philosopher who was my teacher. In the vigor of life he had the same youthful gaiety of heart that now follows him, I believe, into old age. His open forehead, built for thought, was the seat of imperturbable cheerfulness \& joy; the most pregnant discourse flowed from his lips; wit, humour, \& raillery, came to him at will, and his instructions had all the charm of an entertainment. With the same easy mastery with which he tested the doctrines of Leibnitz, Wolf, Baumgarten, Crusius \& Hume, or pursued the discoveries of Newton, Kepler, and other lights of science, he also took up the current writings of Rousseau, such as Emile or Heloise, or any new phenomenon of the natural world, and from the criticism of each, came back to the impartial study of nature, and to the enforcement of the dignity of man. History, in all its branches, natural science, physics, mathematics, and experience, were the materials that gave interest to his lectures and his conversation; nothing worthy of study was to him indifferent; no faction or sect, no selfishness or vanity, had for him the least attraction, compared with the extension and elucidation of truth. He excited \& pleasantly impelled us to mental independence; despotism was foreign to his nature. This man, whom I name with the deepest gratitude \& respect, is Immanuel Kant.”

(1724-1804)

Kant was born in Koningsburg, East Prussia in 1724 of Scotch stock, on the paternal side. His father was a saddler, carrying on a small business. His mother seems to have been a superior woman of deep religious sensibilities. At 16, he entered the University of Koningsburg as a theological student, \& preached occasionally in the country pulpits of the neighborhood. He was poor, took employment as tutor, went from family to family, among people of rank \& others, returned to the University as private lecturer, spending fifteen years in that position, was then and always fond of the study of physical geography \& astronomy published a series of essays \& treatises, became popular as a lecturer, was often sought by persons of distinction.

Thus going on, increasing in fame, we find him at the age of 42 , advanced to the post of an under-keeper of the royal library, at the salary of about $\$ 50$ a year-and four years later promoted to the ordinary chair of logic \& metaphysics, at $\$ 300$ a year. $\mathrm{He}$ ripens slowly. His great work the Critique of Pure Reason, is published in his $57^{\text {th }}$ year. Though in great danger of sinking into oblivion before its importance can be understood, it surmounts that danger, \& in a few years becomes famous. 
We must sum him up briefly started:

Kant analyses, dissects, dissipates the vast suffocating miasma that had so long spread impediments to philosophy - discusses much, clears away, removes, sometimes like a surgeon's knife-yet in fact \& after all decides little or nothing-is of indescribable value - denies the possibility of absolute knowledge of the external world-begins with Hume-admits that we receive all the materials of our knowledge through the sensesbut immediately rises above that admission. Long before, the speculations of Locke \& the other materialists, had reached the formula that "there is nothing in the understanding which has not arrived there through the senses." Leibnitz had replied, "Yes, there is the understanding itself." Kant's entire speculations are but a splendid amplification of this reply. He endeavors to get at \& state the philosophy of the understanding. The problem of the relation between the understanding $\&$ the universes of material nature, he did not attempt to solve.

Note

Perhaps to have begun properly I ought to have mentioned Leibnitz, (1646-1716,) a moralist \& philosopher, by many considered as starting German metaphysics perhaps too timid \& orthodox, when tried by the great standards, but of noblest mind \& powerful influence. His favorite themes were natural theology \& the moral government of the world. In his book, "Theodicee" he exhibits loftiest thoughts \& doctrines. Goodness, benevolence, a harmonious unity in variety \&c. are inculcated all through his pages.

The objection has been taken, \& well taken, that the journey of philosophy beginning in Kant brings us to an uncertainty about every thing. The laws of sight, touch, weight, \&c. are dethroned. Materials \& material experiences amount to nothing. The realities we thought so absolute are only ostensible and are either scattered to the winds or permitted but a passing \& temporary sway.

\section{$\underline{\text { Kant }}$}

Like Socrates and to some extent like Plato he is more a searcher \& tester of systems than a maker of them. Like them, though in his own way, not theirs, he discusses, inquires, suggests, speculates, is very cautious, \& propounds little or nothing absolutely. He clears, frees, removes, seldom absolutely furnishes or fulfills. ${ }^{2}$

Fichte (-1762-1814) commenced life as a poor boy, was sent to school by a wealthy person, received a university education, became tutor in Prussia, was intimate with Kant, absorbed his philosophy, wrote a work which passed for the master's own, traveled through Germany \& Switzerland, married a niece of the poet Klopstock, was appointed professor at Jena, where, in his lectures, he inaugurated \& gradually developed his philosophy, gave offence by some of his notions, resigned, went to Berlin, where he occupied himself in writing $\&$ in giving private lectures, made a great impression on the learned, was appointed professor in the University of Erlangen, was compelled to flee from the invading armies of France, in due time repaired again to Berlin, was appointed rector of the new University of that city, where he died.

Fichte is described as a fervid and telling speaker, but, not so clear or acceptable as writer. His works are voluminous. In his philosophy he begins by declaring for Kant. He founds \& builds largely on the distinction between the $\underline{I}$ and the not I. Upon the fact that a man can only realize anything in its relations to himself, \& from the capacities and measurements that constitute himself, he lays so much stress, that the whole universe, becomes, in brief, the I, as that is the only thinking subject, active principle \& consciousness. His philosophy is simple, single, complete \& logical as far as it goes. There 
will always be a select class of minds, \& superior ones, to which Fichte's theory will be everything. And perhaps there will always be a stage in the progress of every mind which it only will fill \& satisfy or seem to satisfy.

Fichte as will be seen grows out of \& is closely related to Kant. But while the master was satisfied with inquiry, \& at most with love of comprehension of the truth, the follower would put it in practical action. In his peaceful life he was as noble and heroic in his way as the best $\&$ bravest warrior in wars campaigns. Subjectiveness is his principle, explaining all. Strongly stated, nothing exists but the I. And in this, the central fact is ever moral obligation, duty, conscience, giving vitality to all.

[Finale?] ${ }^{3}$ It remains to be inquired - and the inquiry has the most important bearing upon metaphysics \& especially with reference to its future discoveries [Perhaps this is what Fichte finally meant.] ${ }^{4}$ - whether after all allowance for Kant's tremendous \& unquestionable point, namely that what we realize as truth in the objective \& other Natural worlds is not the absolute but only the relative truth from our existing point of view, our temporary stage of development, in other terms, that this is what we realize of the objective world by our present imperfect senses $\&$ cognizance $\&$ that what we thus realize would be entirely changed \& perhaps overthrown \& reversed if we were advanced to superior development \& points of view-It remains, I say, to be inquired [considered] ${ }^{5}$ whether there is not, probably also, something in the Soul, even as it exists under present circumstances, which, being itself adjusted to the inherent and immutable laws of things, which laws \& the principal points of resemblance being the same throughout time \& space, irrespective of apparitions, partialisms, processes, moods does not afford a clue to unchangeable standards \& tests-whether in its abysmic depths, far from ken or analysis, it the soul does not somehow, even now by whatever removes \& indirections, by its own laws, repel the inconsistent, \& gravitate, forever toward the absolute, the supernatural the eternal truth. ${ }^{6}$

Then comes Schelling 1775 to 1854 who professes to largely answer the questions left open by Kant with a doctrine of "spontaneous intuition," in other words, that solve the problem left open by Kant, with the theory that the human mind \& external natural are essentially one. ${ }^{7}$ That that which exists in concrete forms, \&c. in Nature, exists morally and mentally in the human spirit.-The difference between him \& Fichte is that Schelling's philosophy is more largely objective.

The forte of it - seeking to counterbalance and restrain Fichte's all-devouring egoismis the essential identity of the subjective and objective worlds, or, in terms, that what exists as mentality, intelligence, consciousness in man, exists in equal strength \& absoluteness in concrete forms, shows and practical laws in material Nature-making the latter one with man's sane intuitions. The same universal spirit manifests itself in the individual Man, in aggregates, in concrete Nature, and in Historic progress. He elevates Man's reason, claims for it the comprehension of divine things, demands a sort of Platonic ecstasy or inebriation, as the fountain of utterance of first-class philosophy. His palace of idealistic pantheism was never completed-is more or less deficient and fragmentary yet is one of the most beautiful \& majestic structures ever achieved by the intellect or imagination of man. For in Schelling's philosophy there is at least as much imagination as intellect.

It is true no philosophy possible can, in deepest analysis, explain the universe. The least insect, the eyesight, motion, baffle us. No thought can be seized and dissected, and though the corporeal parts \& aggregates can, the main things the atoms \& vitality, remain in mystery. But subtle, vast, electric is the soul, even in present relations, and 
restless and sad, until it gets some clue, however indirect to itself, \& to the relations between itself \& Time, Space and all the processes $\&$ objects that fill them.

Because, final and paramount to all, is man's idea of his own position in the universes of time, space \& materials, his faith in the scheme of things, the destinies which it necessitates his clue to the relations between himself and the outside world, his ability in intellect and spirit at any rate to cope and be equal with them, and with Time and Space. These \& thoughts upon these, come to the soul and fill \& exercise it and remain of vital interest after it has exhausted all other fields. These touch all human beings without exception, and include everything that is of permanent importance to them. They are the greatest themes. They are greater than Science. ${ }^{8}$

While a great part of Literature, speaking in the largest sense, is universal, and applies to all nations, all ages, there is, in another sense, a literature, or at any rate a coloring of literature which belongs to a certain period of time, and to the local genius, character, purposes, history, politics and even the geography of a country, and which, while expressing of course the universal facts, with the coloring and in the spirit of that country, \& adjusted to its circumstances, as marked and distinguished from other countries and ages. ${ }^{9}$

\title{
Religions-Pagan \& Christian
}

Probably the great distinction of the Pagan religions grouped into one, \& led by the Greek theology, is that they appreciated and expressed the sense of Nature, life, beauty, the objective world, and of fate, immutable law, the senses of power \& precedence, \& also, to a greater or lesser degree, the mystery \& baffling unknownness which meet us at a certain point of our investigation of any \& all things. In the Christian cultus, as we get it, instead of these the moral dominates, gentleness, love, the distinctions of right and wrong, the ideas of purity, abnegation of self, terminating often in a diseased benevolence, voluntary penances, celibacy, the bloodless cast-iron virtue, gaunt Calvinism, the harping on "rights," and traversing the extasy of Roman Catholicism, the revolt of Protestantism to Unitarianism, addressed merely to the intellect. ${ }^{10}$

\author{
See big book of \\ extracts \\ different religions \\ Egyptian \\ Jewish- \&c \&c.
}

History, Art, Democracy, or any problems of the Utilities, or prosperity or wealth, or any sectarian Religion. I would not be understood to deprecate the great Departments, the specialties I have just named, but I say that compared with the question of Man, in the visible \& invisible worlds, the others become comparatively insignificant. Yourself, myself,-amid the baffling labyrinths - what am I - what are you here for? - give us some suggestion or clue, however indirect or inferential, or satisfying reason-the world with its manifold shows - the beginningless, endless wonder, Time - the other wonder, Space - oneself, the darkest labyrinth mightiest wonder - what triumph of a man, our kind outtopples this \& has advanced has bestowed on his fellow men the Ariadne's thread to guide them through the maze? ${ }^{11}$

I see to my own satisfaction $\&$ see very clearly, that, to any individual mind, the ambition for universal knowledge is a vain ambition, and that it is already carried to extravagant lengths and taints the schools. But it seems to me the thought of universality - the conception of a divine purpose in the cosmical world \& in history-the realization that knowledges and sciences however important are branches, radiations onlyeach one relative ${ }^{12}$ 
wonderful inventions, discoveries of science, political progress, great engineering works, utilitarian comforts, \&c. of the last hundred years, in a comparatively inferior rank of importance - outstripping them all. Because it assumes to answer \& does answer, as far as they can be answered, the deepest questions of the soul, of identity, of purposes worthy the world, \& of the relation between man and the material Nature \& workings of the external universes, not depreciating them, but elevating man to the spiritual plane where he belongs, and where after all that physical comfort and luxury, with mental culture, \& political freedom can accomplish, he at last finds, and there only finds, a satisfaction worthy of his highest self, and achieves Happiness. ${ }^{13}$

\section{Metaphysics}

\section{- Hegel and Metaphysics ${ }^{14}$}

I will begin by impressing upon your attention the growing and greater particularity with which the moderns use the words relating to those philosophical inquiries. The realms of all words are more or less filling the past, \& will fill the future, getting more definitely bounded. This is one of the marked characteristics of our times. Precision is demanded. Though they inevitably run into each other. Each term in the category has yet its own exact \& limited area, \& the best writer often leaps beyond proof. Science, strictly speaking, deals in positive facts, practical experiments proofs. Philosophy combines them, applies them to solve the vast problem of universal harmony, ensemble, the idea of the all. Religion means moral development, duty, the idea of man's duty in the abstract, \& duty toward his fellows - toned \& colored by that something above him or enclosing him, out of which prayer \& worship arise. Theology is the thought and science of God. Metaphysics, defined by Kant ${ }^{15}$ is according to another \& perhaps still better description, that which considers the whole concrete show of things, the world, man himself, either individually or aggregated in History, as resting on a spiritual invisible basis, continually shifting, yet the real substance, \& the only immutable one. This was the doctrine of Hegel. Georg ? Frederick Hegel, born in Ger died-

(born at Stuttgart ${ }^{16}$

in 1770 .

\section{died 1831}

at Berlin, of cholera)

educated at University of

Tubingen-student of

theology-matriculated in

1788 - aged 18

then, in retirement, pursued

extensive \& severe courses

of study

At 31 was a public lecturer

at Jena, at the University

-was an associate of

Schelling-

examined in his lectures

the difference between Fichte

\& Schelling

- edited a newspaper

- then conducted an academy or a gymnasium

at latter place, (as rector) inaugurated 
\& planned his great work, or workswas professor of philosophy at Heidelberg (1816-1818) and there published his Encyclopoedia, developing his whole philosophy

Hegel was a philosopher in the domain of metaphysics and in that has probably rendered greater service than any man we know, past or present.

Taking the advent of the $19^{\text {th }}$ century for a chronological center, the years surrounding it are probably of an importance in the history of metaphysical science beyond any others known. Metaphysics cognizes that which is above sense, and beyond experience. ${ }^{17}$ All the Four I have mentioned were living, Kant at a great age. Hegel was being formed.

great family of metaphysicians represented by Aristotle, Descartes, \& Leibnitz, Meditations of Descartes. Locke's Essay on the Human Understanding ${ }^{18}$

Only Hegel is fit for America-is large enough \& free enough. Absorbing his speculations, \& imbued by his letter \& spirit, we bring to the study of life here and the thought of hereafter, in all its mystery \& vastness, an expansion and clearness of sense before unknown. As a face in a mirror, we see the world of materials, Nature, with all its objects, processes, shows, reflecting the human spirit, and by such reflection formulating, identifying, developing and proving it. Body \& mind are one; an inexplicable paradox, yet no truth truer. The human Soul stands in the centre, and all the universes minister to it, and serve it and revolve around it. They are one side of the whole $\&$ it is the other side. It escapes utterly from all limits \& dogmatic standards and measurements, and adjusts itself to the ideas of God, of space, and to eternity, and sails them at will, as oceans, and fills them, as beds of oceans.

The varieties, contradictions and paradoxes of the world and of life, and even good and evil, so baffling to the superficial observer, and so often leading to despair, sullenness, or infidelity, become a series of infinite radiations and waves of the one sealike universe of divine action \& progress, never stopping, never hasting. "The heavens and the earth," to use the summing up of a writer Joseph Gostick, whose brief I endorse. "The heavens and the earth, and all things within their compass - all the events of history - the facts of the present, and the developments of the future, (such is the doctrine of Hegel,) all form a complication, a succession of steps, in the one eternal process of creative thought." p.269

\section{Hegel part}

The essential quality, nature, scope, \& position of Man, in Time \& space- What is he? his soul? the relations between it, and this manifold Nature, the world, with its variegated countless objects - the other worlds - the perplexing idea of Immortality-how fuse the material life, the fact of death, chemical dissolution, segregation, with the puzzling thought of Identity's continuance, despite of death-Humanity, the race, History, with all its long train of baffling contradictory events - the tumultuous procession - the dark problem of evil, forming half of the infinite scheme - these are the themes, questions, which have directly or indirectly to do with any profound consideration of [?] ${ }^{19}$ Democracy and finally testing it, as all questions, and as underlying all questions. Who 
advances me to light upon these and without depreciating poets, patriots, saints, statesmen, inventors and the like I rate as Humanity's chiefest teacher and the choicest loved physician, of my mind \& soul. ${ }^{20}$

It is true. Analogy, comparison, indirection, suggestions are perhaps all that is possible. But the soul quickly seizes the divine hints and absorbs them with avidity. The pursuit, or examination \& elaboration of the inquiry: Is a science of metaphysics possible and practicable? involving ${ }^{21}$ the gist of Kant's entire labors, forms (leaving out much that he accepts from others) his own original contribution to Metaphysics itself, and is, in some respects, probably the most illustrious service ever rendered to the human mind- Previous to him, strange as it may seem, no philosopher appears to have troubled himself seriously with this vast impediment rising at the threshold of all metaphysics. Successive dogmatists had sprung up from time to time who had treated and more or less confidently decided, on absolute being, origin of materials, the immortality of the soul, the question of a personal God, and the other problems that have in all ages vexed human reason, and cannot be escaped.

Strictly speaking the transcendental metaphysics present no new contribution to morals, to the formation or guidance of character, the practice of virtue or for the better regulation either of private life or public affairs. With respect to such morals, virtue, or to heroism and the religious incumbency the old principles remain, without notable increase or diminution, the same to-day, as we trace them in farthest India, Egypt, Greece, the Vedas, the Talmud, the Old Testament, Epictetus, Zerdusht, the divine teachings of Christ, and as substantially agreed upon by all lands, all times as far back as we can go.

Religion and morals I say are not palpable affected, although doubtless, there has to be more or less of a re-adjustment \& perhaps re-statement of theology.

Nor does the Hegelian system, strictly speaking, explain the Universe, either in the aggregate or in detail. The senses, eyesight, life, the least insect, growth, the dynamics of Nature are not eclairsised. Thought is not caught, held, dissected. To penetrate Nature \& solve her problems the human faculties under present conditions are no more eligible now than before \& under mortal conditions will, in all probability never be eligible. Hegel appeared. ${ }^{22}$ The eternal mystery is still a mystery. Then after granting this there remains an entirely legitimate field for the human mind, in fact its chosen ground, where all had before gone by default. ${ }^{23}$ query?

? It is certain that what is called revealed religion as founded or alleged to be founded on the Old and New Testament, and still taught by the various churches, in Europe and America, is not responded to by the highest, devoutest modern mind. Having its truth and its purposes in History, and the greatest ones, the time has unquestionably $^{24}$

Penetrating beneath the shows \& materials of the objective world we find, according to Hegel (though the thought by itself is not new but very antique, \& both Indian $\&$ Grecian) that, in respect to human cognition of them, all \& several are pervaded by the only absolute substance which is $\underline{\text { Spirit}}$, endued with the eternal impetus of developement, \& producing, from itself the opposing powers \& forces of the universe. A curious, triplicate process seems the resultant action; first the Positive, then the Negative, then the product of the Mediation between them; from which product the process is repeated \& so goes on without end. In his "Introduction to the Philosophy of History," this is illustrated in the portion on "History as a manifestation of Spirit" 25

\section{p.5 451 Prose Writers}

He has read my Vistas to little purpose who has not seen that the Democracy I favor (if forced to choose,) willingly leaves all material and political successes to enter upon \& enjoy the moral, philosophical \& religious ones. 
I have passingly ${ }^{26}$ mentioned Hegel in the preceding pages but I find I cannot be contented without saying something more elaborate about him, \& what he stands for.

If I were asked to specify who, in my opinion, has by the operation of his individual mind done the most signal service to humanity, so far, I sometimes think my answer would be to point to him and join with his name the name of Kant, and perhaps Fichte, \& Schelling. If I were questioned who most fully \& definitely illustrates Democracy by carrying it into the highest regions, I should make the same answer. There is a close relative-connection, sequence \&c. between all the four even in time.

(They fit into each other like a nest of boxes_-and Hegel encloses them all.

Taking their whole philosophy, it is the most important emanation of the mind of modern ages, and of all ages, leaving even the ${ }^{27}$

Idealism underlies the Four great philosophers, all alike. It does not crop to the surface in Kant, but he necessitates it more than any of them..$^{28}$

\section{Transcendentalism}

-is not only the grandest ante-dating background \& appropriate entrance to the study of any science but to the fit understanding of the position of one's self in Nature, to the performance of life's duties, to the appreciation and application of sane standards to politics and to the judgment upon and construction of works in any department of art, and that by its realization alone is provided a basis for religion and theology that can satisfy the modern.-

These then are the illustrious four, who have originated carried out, with epic succession and completeness, the modern systems of critical and transcendental philosophy. The critical is represented by Kant, who begins \& ends it. The transcendental rises out of $\&$ is founded upon the critical, and could have had no beginning or growth except from its previous existence

\section{NOTES}

1 This phrase is not in Whitman's handwriting; perhaps it is Bucke's notation indicating that he had used "Sunday Evening Lectures" in his 1899 Notes and Fragments.

2 In NUPM 2013, this paragraph is immediately followed by two more paragraphs on Kant:

'Metaphysics, according to Kant-in which he only echoes the general voice of philosophers - is conversant with the world above sense, or beyond experience.' $[\mathrm{He}]$ is occupied with such problems as the nature of absolute being-Ontology. The essence and immortality of the soul-Pneumatology. The prevalance of freedom or fate in the world-Cosmology. The being of God-Speculative theology.

[B] efore Kant two stages: Dogmatism-lots of systems, each affirmed positively - which led by their contradictions and absurdities to: Scepticismtypified in Hume and some of the French philosophs.

In the MS, however, the two paragraphs exist as a separate pamphlet. They are not bound together with the other fragments of text. I have put in square brackets the insertions and capitalization that do not appear in the MS. The paragraphs sound like notes that Whitman was working up for possible inclusion in the Lectures. Bucke may 
have decided to include them in order to make Whitman's thoughts available to his readers, but he or Hubbard may have decided not to bind the pamphlet directly into the other fragments of MS.

3 "Finale" is put in square brackets because it appears in blue pencil with a question mark in the MS. It is not at all clear that Whitman intended this to be the penultimate paragraph of the entire lecture as Bucke suggests in inserting the word into the paragraph and so placing this paragraph in his text.

4 The text in square brackets appears as a marginal note in the MS with a pair of marks indicating placement after the word "discoveries" or a gloss on the sentence. Without the MS Grier has no choice but to follow Bucke in placing this note as a sentence at the end of the paragraph.

5 The word "considered" is written above the word "inquired" in the MS.

6 Compare the MS and NUPM on various phrases that are put in parentheses in this paragraph.

7 The grammar and structure of this sentence are garbled. The MS is unclear.

8 The MS fragment ends here but Grier (NUPM 2011), following Bucke, merges this fragment with another fragment that appears three pages later in the MS. The MS goes from this point to three pages of discussion about literature and religion which are either missing in NUPM or printed separately. See notes 9 and 23.

9 This paragraph is missing in NUPM and in the texts edited by Bucke.

10 This paragraph appears as part of the text of the Sunday Evening Lectures in Bucke's edition but appears as a separate text in NUPM 2038. The MS favors Bucke's original judgement. The issue of the text's overall coherence remains to be decided given the huge divergence in the order of the paragraphs between Grier/Bucke and the MS. Now that the MS has been located, the initial evidence favors the inclusion of this paragraph in the lectures.

11 In NUPM 2011 this paragraph fuses with the paragraph discussed in footnote 23.

12 Grier, NUPM 2017, copies Bucke, who continues this paragraph with another fragment that appears much later in the MS.

13 I place this fragment in the order in which it appears in the MS. Grier follows Bucke and joins this fragment to another passage that appears near the end of the MS. Compare NUPM 2016.

14 This heading appears at the start of this paragraph in the MS. Compare NUPM 2009.

15 Grier (NUPM 2010) follows Bucke and inserts an ellipsis after "Kant" but the MS shows a blank line on the page.

16 From this line until the section beginning "Only Hegel is fit for America" the transcript follows closely the idiosyncratic spacing of the lines as they appear in the MS. This portion of the MS consists of notes and jottings.

17 The MS is unclear about the placement of this sentence. NUPM 2016 is a copy of Bucke's text and inserts part of this sentence as a parenthesis. The MS suggests a complete sentence perhaps placed after the first sentence of the paragraph.

18 This fragment, beginning "great family . ..," appears at this point in the MS. It is not reproduced by Bucke; therefore it is missing from NUPM 2016. • 
19 A question mark appears in the MS in the margin next to the line beginning with "Democracy."

20 Compare NUPM 2012, which construes this sentence as a question and inserts "Hegel" after "I rate." The name Hegel does not appear in the MS.

21 NUPM 2014 has "involves," but the MS is unclear; the word could be "involving." In the margin of the MS, next to the sentence that is underlined, Whitman has written "note what is metaphysics p. $46 \& 47$."

22 This sentence appears in the MS but not in NUPM 2010 nor in Bucke's texts.

23 NUPM 2011 adds more text to this paragraph, but it breaks off here in the MS.

24 No periods, suggesting an ellipsis, appear at the end of this sentence in the MS. Compare NUPM 2018. Bucke decided to place this fragment at the end of the text, as the concluding statement, but the MS does not support that placement.

25 NUPM 2012 follows Bucke in inserting the following text after this paragraph: "He has given the same clue to the fitness of reason and fitness of things and unending progress, to the universe of moral purposes that the sciences in their spheres, as astronomy and geology, have established in the material purposes, and the last and crowning proof of each is the same, that they fit the mind, and the idea of the all, and are necessary to be so in the nature of things." Grier identifies the inserted paragraph as a passage from "Religions.-Pagan and Christian." The inserted passage does not appear in the MS.

26 I add this word from the MS to NUPM 2017; it is also missing from Bucke's transcription of the MS.

27 In the MS the fragment breaks off here. In NUPM 2016 this fragment is joined to one that appears earlier in the MS.

28 In the MS this passage is crossed out. The word "Transcendentalism" appears at the end of this passage and may be the missing word at the start of the next paragraph that follows immediately in the MS. 


\title{
[Diplomatic Transcription by Ed Folsom and Matthew Miller]
}

\author{
Sunday \\ used 2 March '99 [Bucke's handwriting] \\ evening \\ $\underline{\text { Lectures }}$
}

Kant born 1724 to 1804

Fichte 1762 to 1814

Schelling 1775 to 1854

died in Switzerland

Hegel 1770 to 1831

[page break]

Enc. Brit. Vol. 13. p. 46

I. K.

moral portrait of him by

Herder, 1795.

"I have had the good fortune to know a philosopher who was my teacher. In the vigor of life he had the same youthful gaiety of heart that now follows him, I believe, into old age. His open forehead, built for thought, was the seat of imperturbable cheerfulness \& joy; the most pregnant discourse flowed from his lips; wit, humour, \& raillery, came to him at will, and his instructions had all the charm of an entertainment. With the same easy mastery with which he tested the doctrines of Leibnitz, Wolf, Baumgarten, Crusius \& Hume, or pursued the discoveries of Newton, Kepler, and other lights of science, he also took up the current writings of Rousseau, such as Emile or Heloise, or any new phenomenon of the natural world, and from the criticism of each, came back to the impartial study of nature, and to the enforcement of the dignity of man. History, in all its branches, natural science, physics, mathematics, and experience, were the materials that gave interest to his lectures and his conversation; nothing worthy of study was to him indifferent; no faction or sect, no selfishness or vanity, had for him the least attraction, compared with the extension and elucidation of truth. He excited \& pleasantly impelled us to mental independence; despotism was foreign to his nature. This man, whom I name with the deepest gratitude \& respect, is Immanuel Kant." - his image rises before

[page break]

$177(1724-1804)$

Kant was [^ ${ }^{\wedge}$ born in Koningsburg, Eastern Prussia in 1724] of Scotch stock, on the father's side paternal side. His father was a saddler, carrying on a small business. His mother seems to have been a superior woman of deep religious sensibilities. At 16, he entered the University of Koningsburg as a theological student, \& preached occasionally in the [^ country] pulpits of the neighborhood. He was poor, made a took employment as teacher and tutor, went from family to family, noble p[?] among people of rank \& others, returned to the University in the post as private lecturer, spending fifteen years in that position, was $\left[{ }^{\wedge}\right.$ then and] always fond of the study of physical geography $[\wedge$ 
\& astronomy] published a series of essays \& treatises, became popular as a lecturer, often was often sought by persons of distinction. If Thus going on, increasing in fame, we find him at the age of 42 , advanced to the post of an under-keeper of the royal library, at the modest salary of about $\$ 50$ a year-and four years later promoted to the [page break: inserted here is a page with the menu of the Ninth Annual Banquet of the Walt Whitman Fellowship, May 31, 1902] ordinary chair of logic \& metaphysics, at $\$ 300$ a year. He ripens slowly. His great work the Critique of Pure Reason, is published in his $57^{\text {th }}$ year. The da dan[?] It was some time before At first in danger $\left[{ }^{\wedge}\right.$ Though tikety in great danger] of sinking into oblivion before its importance can be [? understood, it surmounts that danger, $\&$ in a few years becomes famous.

\section{[page break]}

[In left margin: Will expand]

\section{We will eome to}

But the real beginner diseoverer,

We must sum him up briefly started:

Kant analyses, dissects, dissipates the vast suffoeating blinding mountains of flummery previously established or suffered as [^ elouts miasma that had so long spread $\{?\}$ as blinds] impediments to philosophy- $\left[{ }^{\wedge}\right.$ discusses much,] clears away, removes, $\left[{ }^{\wedge}\right.$ sometimes] like a surgeon's knife-yet diseusses mueh [^ in fact \& after all] decides little or nothing - yet is of indescribable value - denies the possibility of absolute knowledge of the external world - begins with Hume - admits that we receive all the materials of our knowledge through the senses - there [^ ${ }^{\wedge}$ but immediately] rises $[\wedge$ far] above that admission. Long before, the speculations of Locke $\&$ the other materialists, [^ had] reached the formula that "there is nothing in the understanding which has not arrived there through [page break] the senses." Leibnitz had $\left[{ }^{\wedge}\right.$ had] replied, "Yes, there is the understanding itself." Kant's entire speculations were in brief but an [^ are but a splendid] amplification [^ starts out from and] of this reply. He endeavors to $[\wedge$ get at $\&$ ] state the philosophy of the understanding. The $[\wedge$ problem of the] relation between the understanding $\&\left[{ }^{\wedge}\right.$ the universes of] material nature, the universe has las he did not attempt to solve.

\section{[page break]}

\section{? Note [in left margin: *yes note]}

Perhaps to begin [^ have begun] properly I ought to [^ have] mentioned Leibnitz, (16461716 ,) a moralist $\&$ philosopher, $\left[^{\wedge}\right.$ by many considered as starting German metaphysics] perhaps too timid \& orthodox, when tried by the great standards, but still of noblest $\&$ mind \& great [^ powerful] influence. His favorite themes were natural theology $\&$ the moral government of the world. In his [^ book,] "Theodicee" he exhibits his [?] prineipal [^ loftiest] thoughts \& doctrines. Goodness, benevolence, a harmonious unity in variety $\& c$. are his are inculcated appear all through his pages.

[page break: inserted here on a blank page is the photoengraving of Whitman used at the frontispiece for November Boughs]

The objection has been taken, \& well taken, that the general result [ ${ }^{\wedge}$ the journey] of the [?] philosophy beginning in Kant is ieonoelastie but [^ and] teaves us with[?] [^ brings us to an] uncertainty of [^ about] every thing. The laws of sight, touch, weight, \&c. are dethroned. [?] [^ Materials \&] material experiences amount to nothing. The realities we thought so reat $\left[{ }^{\wedge}\right.$ absolute] are only ostensible and are either onty either $[\wedge$ 
but] permitted but [^ but] a passing \& temporary sway or are scattered to the winds. or permitted but a passing $\&$ temporary sway.

[page break]

$\underline{\text { Kant }}$

Like Socrates and [^ ${ }^{\wedge}$ to some extent like] Plato he is more a searcher a $[\wedge \&$ tester of systems] than a maker of systems [^ them]. Like them, though in his own way, $\left[{ }^{\wedge}\right.$ not theirs, ] he [?] discusses, inquires, suggests, speculates, more [ ${ }^{\wedge}$ is very cautious, $\&$ propounds little or nothing absolutely. He clears, frees, removes, seldom filts. [^ ${ }^{\wedge}$ absolutely furnishes or fulfills]

\section{[page break]}

Fichte $\left[^{\wedge}(-1762-1814)\right]$ commenced life as a poor boy, was sent to school by a wealthy person, received a university education, became tutor in Prussia, was intimate with Kant, absorbed his philosophy, wrote a work which passed for the master's own, traveled through Germany \& Switzerland, married a niece of the poet Klopstock, beeam was appointed professor at Jena, where, in his lectures, he gradtually inaugurated \& gradually developed his philosophy, gave offence by some of his notions, resigned, went to Berlin, where he occupied himself in $j$ writing $\&$ in giving private lectures, made a great impression on the learned, was appointed professor in the University of Erlangen, was compelled to flee [page break] from the invading armies of France, again in due time repaired again to Berlin, was appointed rector of the new University of that city, where he died.

Fichte [ [^ is described as] a fervid and telling orator speaker, and but, though [^ equally] earnest as writer not so clear or acceptable as writer $\left[{ }^{\wedge}\right.$ writer] [^ author]. ${ }^{\wedge}$ His works are voluminous.] In his philosophy he begins by declaring for Kant. He is the author of [^ begins begins largely founds \& builds largely on] the distinction between the I and the not I. (the objective-wortel.) Upon the fact that a man can only realize anything in its relations to himself, \& from the capacities and measurements that constitute himself, he lays so much stress, that the whole universe, becomes, in brief, the I, as [^ as that is] the only thinking subject, the active principle \& consciousness. His philosophy is simple, single, and complete $[\wedge \&$ logical] as far as it goes. There will always be a select class of minds, \& superior ones, to which Fichte's theory will be every thing. And perhaps there will always be a stage in the proeessgress of every mind which it only will fill \& satisfy or seem to satisfy.

\section{[page break]}

Fichte follow [^ ${ }^{\wedge}$ as will be seen grows out of] \& is closely related [^ \& was [?] personally with him] to Kant. But while the master was satisfied with inquiry, \& at most with [^ love of] comprehension of the truth, the follower would put it in practical action. $\left[^{\wedge}\right.$ In life his peaceful life] $\mathrm{He}$ was as noble and heroic in [^ tiving] philosophy his way as a the best [inserted: \& bravest] warrior [^ in wars campaigns.] [?] after his sort, in the eampaign. Subjectiveness is his principle, explaining all. [^ Strongly stated,] Nothing exists but the I. And in this, the central fact is ${ }^{\wedge}$ ever] moral obligation, duty, conscience, giving vitality to all.

[page break: inserted here on a blank page is a photo of Whitman with a butterfly, with Whitman's signature below it, and above it, in script, "For Elbert Hubbard this Whitman autograph from RM Bucke".] 
[In left margin: ?Finale?] It remains to be suggested [^ inquired-] in and the suggestion [^ inquiry] has the most important bearing upon metaphysics \& especially [inserted at top of page with line connecting it: with reference to its future discoveries*-] [In left margin: *Perhaps this is what Fichte finally meant.] whether That after all allowance [^ is made] for Kant's tremendous \& unquestionable point, [^ namely] that what we realize as truth in the objective $\&$ other [^ Natural] worlds is only not $\left[{ }^{\wedge}\right.$ the] absolutely but only the relatively true $\left[{ }^{\wedge}\right.$ truth] from our existing point of view, ${ }^{*}\left[{ }^{\wedge}\right.$ our temporary stage of development, [ [^*in other terms, that this is what we realize of the objective world by our present imperfect senses $\&$ cognizance] \& $\&$ ould $\left[\wedge\right.$ that] what we $\left[^{\wedge}\right.$ now thus] realize of the wortd would be entirely changed $[\wedge$ \& eonsigned to futility \& perhaps overthrown \& reversed] if we were advanced to superior [^ ${ }^{\wedge}$ development $\&$ ] points of view-It remains [^ I say] to be inquired, [^ considered] Isay, whether there is not, [^ probably] also, something in the Soul, [^ even as it exists under present circumstances, ] which, being a itself adjusted to the inherent and immutable nature [^ which laws \& the principal points of resemblance being the same] throughout all time \& space, irrespective of apparitions, mutations, $[\wedge$ partialitiesisms, processes, moods] does not afford by indireetion perhaps, some elue to absolute eternal truth \& whether after all [page break] a clue to absolute [^ unchangeable] standards \& tests-whether in its abysmic depths, far from ken or analysis, it [^ the Soul] does not somehow, $\left[^{\wedge}\right.$ even now] by whatever removes $\&$ indirections, it does not realize the absolute by the the absolute, the eternal turn far from what the dee [^ deteet by its own laws,] deteet [^ repel] the inconsistent, \& tean, [^ ever gravitate], forever pleased to toward the absolute, $\left[{ }^{\wedge}\right.$ the supernatural] the eternal best truth.

\section{[page break]}

Then comes Schelling [^ 1775 to 1854 ] who professes to [^largely] answer the questions [^left open by Kant] by an his [^with the a] doctrine of "spontaneous intuition," [?] in other words, that [^ solve the problem left open by Kant, with the theory that] the human mind \& external natural are essentially one. That [^ that] which exists in concrete forms, \&c. in Nature, exists morally and mentally in the human spirit. -The difference between him \& Fichte is that Schelling's philosophy is [^more] largely objective, atso

[page break: inserted here is a blank page with a profile photo of Whitman; below it is Whitman's signature, followed by "From RM Bucke To Elbert Hubbard".]

The ehief forte of Sehellings philosophy [^ ${ }^{\wedge}$ it] — seeking to counterbalance and restrain Fichte's all-devouring egoism-is the essential identity [^ \& perhaps equatity] of [^ ${ }^{\wedge}$ the] subjective and objective worlds, or, in terms, that the what exists as mentality, intelligence, consciousness in man, the same exists [ ${ }^{\wedge}$ in equal strength $\&$ absoluteness] in concrete forms, \& shows [^ \& practical laws] in material Nature-making all the latter one with man's sane intuitions. [Inserted in left margin: The same universal spirit manifests itself in the individual Man, $\{\wedge$ in aggregates, $\}$ in $\{\wedge$ concrete $\}$ Nature, and in Historic progress.] [^ $\mathrm{He}$ elevates Man's reason, claims for it the comprehension of divine things, demands a sort of Platonic ecstasy or inebriation, as the fountain of utterance of first-class philosophy.] His beautiful \& majestie strueture $[\wedge$ palace] of idealistic pantheism was never f completed-is more or less [^ deficient and] fragmentary but it is one of the most gorgeous [in left margin Whitman subtracts 1775 from 1741 \{sic\} and comes up with 66] [page break] is yet $\left[^{\wedge}\right.$ is] one of the proudest aehievements [^ most beautiful $\&$ majestic structures ever achieved by] of the intellect $\left[{ }^{\wedge}\right.$ or imagination] of man. For in Schelling's philosophy there is at least as much imagination as intellect.

[page break: the next page contains two pasted fragments] 
It is true no philosophy possible can, in deepest analysis, explain the universe. The least insect, the eyesight, motion, really moek baffle us. For men[?] [?] [^ ${ }^{\wedge} \mathrm{No}$ thought can be seized and dissected, and though the corporeal [? $?$ ]parts $\&$ aggregates can, $[\wedge$ the main things] the atoms $\&$ the vitality, remain in mystery. But so subtle, vast, electric is the hum soul, even in present [fragment break] relations, and so lost ${ }^{\wedge}{ }^{\wedge}$ is and restless] and sad, until it gets the some clue, however indirect between to itself, $\&$ to its ${ }^{\wedge}{ }^{\wedge}$ the] relations between itself $\&$ Time, and Space and $[\wedge$ and with and] all the for filt processes $[\wedge \&$ objects] that fill them \& all the objeets.

\section{[page break]}

Because, what is of final and paramount to all, is Man's opinion of himself his possession of some satisfaetory his satisfaetion [^ his idea of his own position in the universes of time, space $\&$ materials, ] his faith in the scheme of things, ${ }^{\wedge}$ the destinies which it necessitates] his clue to the relations between himself and the materiat ${ }^{\wedge}$ outside] world, and his ability $[\wedge$ in intellect $\&$ spirit at any rate] to cope and be equal with $[\wedge$ to] them, and with Time and Space. These $[\wedge \&$ thoughts of upon these,] come to the mind $\left[\wedge\right.$ soul] and fill \& exercise it $\left[^{\wedge}\right.$ and remain of vital interest] after it has exhausted previous [^ \& tired of let other all other] fields. These are the These touch all human beings, and settle all that is of without exception, and so include all every thing that is of any permanent importance [^ ${ }^{\wedge}$ to them.] They are [^ ${ }^{\wedge}$ indeed] the greatest themes. They are greater than Science.

\section{[page break]}

While a great part of Literature, speaking in the largest sense, is universal, and applies to all nations, and all ages, there is, in another sense, a literature, $[\wedge$ or at any rate a coloring of literature] which belongs to an a certain period of time, as advaneed be= yond f others and to the $\left[^{\wedge}\right.$ local] genius, an character, and $m$ purposes, history, $\left[^{\wedge}\right.$ politics] and even [^ the] geography of a country, and which, while given $[\wedge$ expressing of course] the universal facts, expressed $\{s\}$ f them from the premises, in $\left[{ }^{\wedge}\right.$ with] the coloring and in the spirit of that country, $\left[{ }^{\wedge} \&\right.$ adjusted to its circumstances age], as marked and distinguished from other countries and ages.

[page break: inserted here is a blank page with a photograph of Whitman standing, holding his hat in his hand, numbered 1860s-\#1 in WWQR "Whitman Photographs" issue]

Religions-Pagan \& Christian

Probably the great distinction of the Pagan religions grouped into one, \& led by the Greek theology, as compared with the Christian eultus is that they former appreciated and expressed the sense of Nature, life, beauty, the objective world, and of fate, immutable law, [^ the senses of] power $\left[{ }^{\wedge} \&\right.$ precedence], \& also, to a mo greater or lesser degree, of [^ especially in Egypt] the mystery \& [^ baffling] unknownness which finally meet us at the end of [^ a certain point of] our investigation of any \& all things. Christianity [^ In the Christian cultus, as we get it, instead of these] the moral to more dominates, gentleness, love, the distinctions [page break] of right and wrong, the ideas of purity, abnegation of self, terminating [^ tending to] often in a diseased benevolence, voluntary penances, celibacy, and that ridieu ridieutous and ${ }^{\wedge}$ the bloodless cast-iron virtue ${ }^{\star}$, \{written in top margin: *gant gaunt Calvinism, \} the] harping on "rights," and the retigion of Unitarianism [?] adtressed merely to [?] intelleet. [^traversing the extasy 
of Roman Catholicism, the revolt of Protestantism to Unitarianism, addressed merely to the intellect.] [written just before the previous insertion:

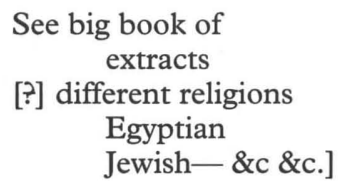

[page break]

History, Art, Democracy, or any seetarian [^ problems] of the Utilities, $\left[^{\wedge}\right.$ or materiat prosperity or wealth,] or any sectarian Religion. I would not be understood to deprecate [^ the great Departments, the specialties] compared with] the problem question of $\operatorname{Man}\left[{ }^{\wedge},\right]\left[{ }^{\wedge}\right.$ in Time \& spaee, ] in the material [^ visible $\&$ invisible] worlds, \& in time \&space, they [^ ${ }^{\wedge}$ the others] [?] teseend into [^become] comparatively insignificant $[\wedge$.] positions. Yourself, $[\wedge$ myself, -amid] $[\wedge$ the baffling labyrinths - ${ }^{\star}$ ] [written in top margin: ${ }^{\star}$ - what $\{\wedge$ am I-what $\}$ are you hea here for? - what does it mean? - give us some suggestion or clue, $\{\wedge$ however indirect or inferential\}, or satisfied \{^satisfying\} reason-] the world with its manifold showsthe beginningless, endless wonder, Time - the other wonder, Space- History that has the [^ yourself oneself, the mightiest $\{\wedge$ darkest $\}$ labyrinth $\{\wedge$ mightiest wonder $\}]$ - has the what triumph of the mind of man exeects [^ our kind outtopples] this That one [^ a man a mind has existed $\{\wedge$ lived\} \& has advanced] has tived who the out of the $[\wedge$ eountless] complex seas and under seas of $[\wedge$ bestowing] and given $[\wedge$ to give bestowed on his fellow minds [^ men] the guriding [^Ariadne's] thread. to guride [^ teadl guide them through the maze?

\section{[page break]}

I see to my own satisfaction $\&$ see very clearly, that, [^ for to any individual mind, ] the ambition for universal knowledge is a vain ambition, \& $\left[\wedge\right.$ hat] $f$ think the ide ${ }^{\wedge}$ and that it] already carried to extravagant lengths $\left[^{\wedge}\right.$ and $\{?\}$ taints the schools.] But it seems to me the thought of universality - the conception of a eentrat divine purpose in the cosmical world \& in history \& [^ - the realization] that all knowledges and sciences $[\wedge$ however important] are but branches, of radiations that there is a God, only - noone really each one relative

[page break: inserted here is a page with the William Linton 1876 engraving of Whitman pasted in]

[?] wonderful inventions, $[\wedge$ discoveries of] science, political progress, $[\wedge$ great engineering works,] utilitarian comforts, \&c. of the last hundred years, of andall the kindred $[\wedge$ vaunted] material triumphs of today, in an [^ a comparatively] inferior rank of importance- out $[?]$ \& on far outstripping them all [^ \{?\} all.] Because it it satis assumes to answer $\&$ satisfy [^ does answer, as far as they can be answered,] the last deepest questions of the soul, of identity, [^ of a purposes worthy the universe world,] a $\&$ of the reat relation between these man and the shows \& the material forms [^Nature shows Kosmos] $\&$ workings of the external universes, $[\wedge$ not $\{?\}$ depreciating them, but] elevating man to the spiritual plane where he belongs, and where after all that physical [^ ${ }^{\wedge}$ comfort and] luxury, [?] [^ with] mental culture, \& political freedom can accomplish, he at last finds, and there only finds, a satisfaction worthy of his highest self, $[\wedge \&$ achieves Happiness] [In left margin, from "external universes" to the end, is a line with two large question marks.] 
- What rare whar herefor? - tot

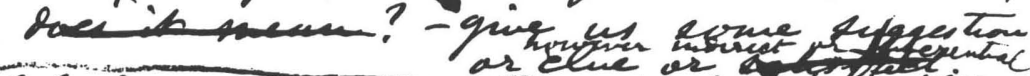

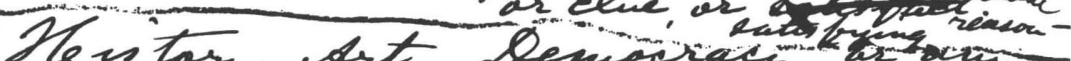

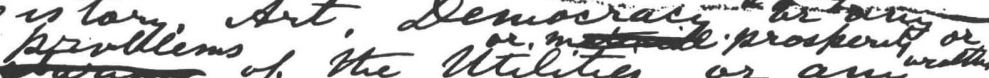
20 itilites, or any sectarian Religion. Dwould nt he understod to de the orent oxpantment the regraltime jinct numes recate whet

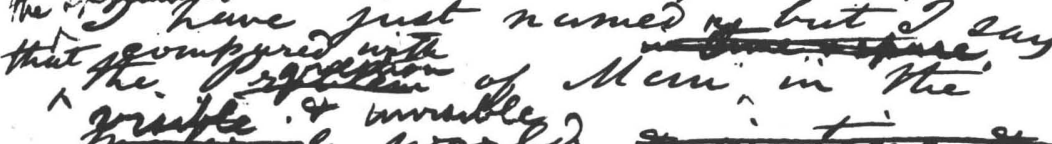
preste wores, Ifapte, ther den

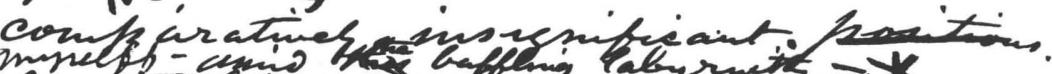
Ofourself it the wares, with ts $X$ nunifols shows - the beginmagles, endless waxder fine the othe

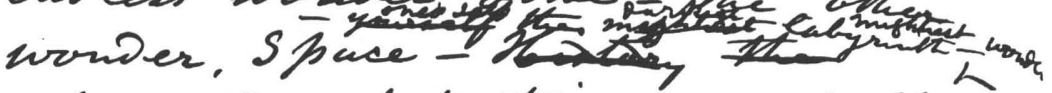
- tor what tringles of the

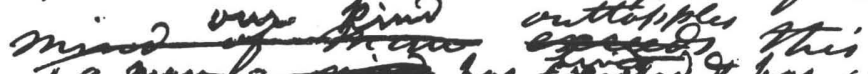

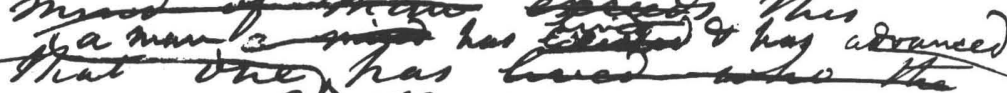

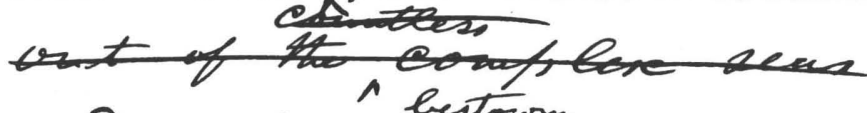
and ponder bestown

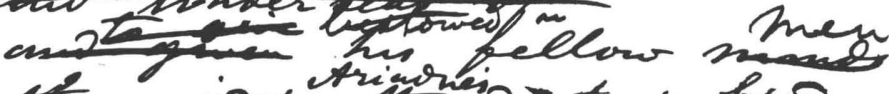

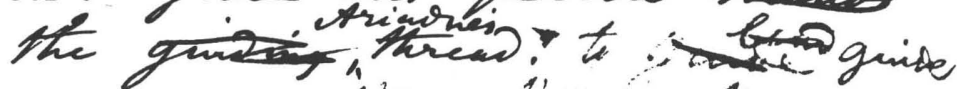
fterw tiverigh the marze?

Manuscript page of Whitman's "Sunday Evening Lectures." Harry Ransom Humanities Research Center, The University of Texas at Austin. See transcription on p. 125. 


\section{Metaphysics \\ -Hegel and ? Hegetism [^ inquiries ^ metaphysieal] [^ Metaphysics]}

I will begin by tesiring [?] impressing more-arefully upon your attention the growing and greater particularity of the words us of our use with which we ${ }^{\wedge}$ our modern times use we $\{\wedge$ the $\}$ moderns use] the words relating to [^ those philosophical] [?] [^ great $\{\wedge$ great $\}]$ inquiries. [^ that we inherit from all past times] [^ - the inquiries that have prevented] Realms The [?] realms of $\left[{ }^{\wedge}\right.$ important] all $[\wedge$ all] words indeed $[\wedge$ throw] are [?], [^ more or less filling the past \& will fill the future, $\&$ more $[\wedge$ now] [^ getting more] definitely bounded. This is one of the $\left[{ }^{\wedge}\right.$ marked] characteristics of the moderns [^ ${ }^{\wedge}$ of our times]. sei $p$ Precision is demanded. The true seientist is [ ${ }^{\wedge}$ Though they inevitably run into each other. Each term in the category has $\{\wedge$ yet\} its exaet own exact $\&$ limited area, \& the best writer often leaps beyond the proofs faets]. Science, strictly speaking, deals in positive facts, practical experiments proofs. Philosophy combines them, applies them to the gr solve the great [^ vast] problem of the universal [?] harmony, ensemble, the idea of the all. Religion is means [page break] the moral development, dut duty, $\left[^{\wedge}\right.$ the idea of $\{\wedge$ man's $\}$ duty of $\{?\}\{?\}$ in the abstract, \& duty toward his fellows- $]$ [?] partaking of [^ $\{$ ? $\}$ in toned \& colored by] that something [^ above him or enclosing him,] out of the which prayer \& worship arise. Theology is the thought \& science of God. in Metaphysics, defined by Kant [blank space] is in [^ according to] another [^ \& perhaps still better] [^ concrete show] frame of things, the eonerete world, and man himself, either [?] an individually or aggregated in History, as resting on a spiritual invisible basis shifting bas basis, continually shifting, yet the real substance, $\&$ the only immutable $[\wedge$ one]. This was the doctrine of Hegel. Georg ? Frederick Hegel, born in Ger died-

\section{[page break]}

(born at Stuttgart

in 1770 .

died 1831

at Berlin, of cholera)

educated at University of

Tubingen-student of

theology-matriculated in

1788 - aged 18-

then, in retirement, pursued

extensive \& severe courses

of study

[page break: the next page consists of two pasted fragments]

At 31 was a public lecturer

in Jena, at the University

-was an associate of

Schelling- teetured

- examined in his tet lectures

the difference between Fichte

\& Schelling

- then edited a newspaper 
— then conducted [^ an academy or] a gymnasium

[fragment break]

at latter place, (as rector

of gymmasium) inaugurated

\& planned his great work,

or works-

was professor of philosophy

at Heidelberg (1816-1818)

and there published his

Encyclopaedia, developing

his whole philosophy

[page break: inserted here is a photograph of Whitman by Frederick Gutekunst, numbered 1880s \#1 in WWQR "Whitman Photograph" issue]

Hegel was a philosopher in the domain of metaphysics and in that has probably rendered greater service than any man that we know, past or present.

[page break: the next page consists of three pasted fragments]

Taking the advent of the $19^{\text {th }}$ century for a chronological center, the years surrounding it are $\left[{ }^{\wedge}\right.$ probably of an importance] the most important in the history of $\left[{ }^{\wedge}\right.$ metaphysical science $\left.{ }^{\star}\right]$ philosophy of $\left[{ }^{\wedge}\right.$ beyond] any [^ others] known. All the [^ divine great seien= tists] Four [^ $\mathrm{I}$ have mentioned] were living, Kant at a great age. Hegel was being formed.

\section{[fragment break]}

great family of metaphysicians represented

by Aristotle, Descartes, \& Leibnitz,

(Meditations of Descartes.

Locke's Essay on the Human Understanding

[fragment break]

*Metaphysics cognizes that which is above sense, and beyond experience.

[page break]

[^ Only Hegel is fit for America-is large enough \& free enough.] Become-Absorbing Hegel's his speculations, \& beeoming imbued ${ }^{\wedge}$ ith ${ }^{\wedge}$ by his letter $\&$ spirit, the we [^ eertainly get] took on [^ bring to the study] of life here $[\wedge$ and the etues $\{\wedge$ thoughts of\} here and hereafter,] in all its mystery \& vastness, with an expansion and clearness of sense before unknown. [ ${ }^{\wedge}$ As a face in a mirror, we see] The worlds of materials, the passion Nature, with all their [^ ${ }^{\wedge}$ its] objects, processes, shows, while reflecting the human spirit, and [^ these] having for its purpose to formulating, identifying, and developing [^ and $\{\wedge$ by such reflection $\}$ proving] it by. $B$ [?] Body \& sout [^ mind] are one; an inexplicable paradox, yet no truth truer. The human Soul stands in the centre, and all the universes minister to it, and serve it and revolve around it. $\left[^{\wedge}\right.$ They are one side $\left\{^{\wedge}\right.$ of the whole $\} \&$ it is the other side.] It adjusts itself. It escapes utterly from the $\left[^{\wedge}\right.$ all previous and limited for limits \& dogmatic] standards and measurements, previously and adjusts itself to measureless [^ the free oeeans of] [^ the ideas of God, of] space, and 
to eternity, and sails over them at will, [^ ${ }^{\wedge}$ as oceans, ] and fills them, as beds of oceans.

\section{[page break]}

The varieties, and contradictions and paradoxes of the world and [^ of] life, and even good and evil, so baffling to the superficial observer, and so often leading to despair, sullenness, or infidelity, become whenviewed by the Ifeglight of Iegel's phitosophy, the [^ a series of] infinite variab radiations and waves of an immense oeean [^ sea] $[\wedge$ the one sea-like universe] of divine action $\&$ progress, never hasting $[\wedge$ resting stopping,] never hasting, adjusted not to the petty seales \& standards of what we human life here, but to the limitless areas of time \& space "The heavens and the earth," says [^ to use the summing up of] a writer Joseph Gostick, whose brief of this philosophy [^ of Hegetianism] I endorse [^ endorse \& give]. "The heavens and the earth, and all things within their compass - all the events of history - the facts of the present, and the developments of the future, (so such is the [^ doctrine teaet] philosophy of Hegel,) all [^ form] a suee complication, a succession of steps, in the one eternal process of creative thought." p.269

\section{[page break]}

\section{[written in top margin:] Hegel part}

The essential quality, nature, \& scope, [^ \& relative position] of Man, in the universe Time \& space- What is he? his soul? What the $\left[^{\wedge}\right.$ the the] relations between it, and this manifold Nature, the world, $[\wedge$ with] its variegated $[\wedge$ countless] objects - the number= tess other worlds - Immor the perplexing idea of Immortality [^ - the] - how? how teat fuse the material life, the fact of death, diss chemical dissolution, segregation, with the [?] [^ puzzling] thought of Identity's continuance, $\left[^{\wedge}\right.$ despite of death-] Humanity, the race, History, with all its long train of baffling $\left[^{\wedge}\right.$ contradictory] events - the tumultuous procession - the dark [page break] problem of evil, forming half of the [^ infinite] scheme - these are the themes, questions, which have finally $[\wedge$ directly or indirectly] to do with any profound consideration of ["?" in margin] Democracy [^ and finally testing it,] as of all questions, and $[\wedge$ as] underlying all questions. Who advances $[\wedge$ me to] the light upon these $[\wedge \mathrm{I} \mathrm{I}$ eall] in is Itumanities ehiefest teacher \& physieian, and $[\wedge$ and and] without depreciating poets, patriots, saints, $[\wedge$ statesmen, ] inventors and the like [^ I rate as Humanity's] is my chiefest teacher and $\left[^{\wedge}\right.$ the choicest] loved physician, of my [^ its my] mind \& soul.

[^ It is true.] Analogy, comparison, indirection, suggestions are it is true [^ perhaps] all $p$ that perhaps is possible. But the soul quickly seizes the divine hints and absorbs them [?] with avidity.

[page break]

The gist and amount of Kant's labors are invol [?] Kant's whole

The [^ pursuit, or examination \& elaboration of the] inquiry: Is a science of metaphysics* possible and practicable? [In left margin: note what is metaphysics p. 46 \& 47] in the same way that a seienee of [?] [?] involving the prineipal amount \& val gist of Kant's [?] $[\wedge$ entire] labors, $[\wedge$ and] and what he has contributed $[\wedge$ and $\{?\}]$ in that examination advaneed forms [^ (leaving out much that he accepts from others)] his or own original contribution to Metaphysics itself, and is, in some respects, $[\wedge$ probably] the most pre= eious illustrious service ever rendered to the human mind-Previous to him, noone-so strange as it may seem, no philosopher appears to have first thought it obligatory in 
eumbent upon troubled himself seriously with this [^ ${ }^{\wedge}$ vast tremendous impediment] problem wich stands $[\wedge$ rising] at the threshold [page break] of all metaphysics. Successive philosophers $[\wedge$ dogmatists] had arisen $[\wedge$ sprung up] from age to age $[\wedge$ time to time] who had [^ had treated and more or less] confidently presented their systems elass and decided, by their dogmatic solutions the problems of $[\wedge\{?\}$ on] absolute being, materiat origin of materials, the [?] the immortality of the soul, the [?] [^ question] of a personal God, and the other problems [?] that have in all ages vexed human reason, and cannot be escaped.

\section{[page break]}

\section{The Heget}

[^ Strictly speaking] The transcendental metaphysics does present nothing new for the regulation of private life for morals or [^ ${ }^{\wedge}$ no new contribution] to morals, to the formation $\left[\wedge\right.$ or guidance] of character, the practice of virtue of or for the $\left[^{\wedge}\right.$ better] regulation $\left[\wedge\right.$ either] of preither private $\left[\wedge\right.$ life] or public affairs. With respect to $\left[^{\wedge}\{?\}\{\wedge\right.$ such $\}]$ morals, virtue, $\left[\wedge\right.$ or to] heroism the and $\left[^{\wedge}\right.$ the] religious incumbency the [?] ${ }^{\wedge}$ $\{?\}$ old] principles remain, [^ without notable increase or diminution, ] the [?] fet ever new, alike in all times, all lands, agreed upon by all the sages and times and all tands the same to-day, as we get [^ find trace] them from [^ ${ }^{\wedge}$ in] farthest Egy India, Egypt, Greece, the Vedas, the Talmud, [page break] the Old and $\left[^{\wedge}\right.$ Testament,] Epictetus, Zerdusht, the divine teachings of Christ, agr [^ ${ }^{\wedge}$ and as] substantially agreed upon by all lands, all times, [^ indifferently to day or] as far back as we can go. Using the te

Religion and morals [^ I say] are not palpably affected, although doubtless, [?] there has to be more or less of a re-adjustment \& perhaps re-statement of theology.

[page break: inserted here is a page with a pasted-on check written to Walt Whitman on December 8, 1890, in the amount of five dollars, from John H. Johnston \& Co.]

Neither-[^ Nor] does the Hegelian system, [^ eontribution, \{^ system, $\}]$ strictly speaking, explain the Universe, either in the aggregate or in detail. The eternal mystery remains a mystery is [ [ ?] a mystery still. The [?] senses, eyesight, the [?] [?] life, the least insect, the growth, the dynamics of Nature are not eclairsised. Thought is not caught, held, dissected. Not a But if [^ the] transeendental metaphysies be the true and com= prehensive system $\left[\wedge\right.$ To penetrate here $\{\wedge$ Nature $\} \&$ solve the $\left\{{ }^{\wedge}\right.$ her $\}$ problems, The human faculties under present conditions \& times $\left[{ }^{\wedge}\right.$ are] no more eligible now than before [ ${ }^{\wedge} \&$ under mortal conditions will, in all probability never be eligible.] Hegel appeared. [“?” in margin] The eternal mystery is still a mystery. But in the event [^ Then after granting this] there is $[\wedge$ remains] an entirely legitimate field for the human mind, in fact its chosen ground, where all had before gone by default.

\section{[page break]}

\section{[at top of page:] ?query?}

It is certain that what is called revealed religion and the speeifie as illustr and its points and tenets as founded or alleged to be founded on the [?] Old and New Testament, and expounded [ ${ }^{\wedge}$ still taught] by the $[\wedge$ various] churches, in Europe and America, toes is not responded to by the [^ highest, devoutest] modern mind. Having [^ its truths and] its purposes in History, and the greatest ones, and its strengths the [?] time has unquestionably 
Penetrating beneath the shows [^ \& materials] of the objective world $[\wedge$ we find that consider, \{written in top margin: according to Hegel (though the thought by itself is not new (it but very antique, \& both Indian \& Grecian) $\}]$ all and severat [^ that, in respect to human cognition of them, all \& several] are pervaded by the only Absolute substance which is Spirit, endued with the [^ eternal] impetus of eternat developement, $\&[\wedge \&]$ producing, from itself the eternal po opposing powers $\&$ forces of the universe [^ (This is old and $\{\wedge$ both\} Greeian \& Indian $\{\wedge \&$ Greeian\} $\}]$. The resulting aetion is $[\wedge$ A curious, endless] triplicate process seems [^ always] the resultant action; first the Positive, then the Negative, then a third result from $\left[{ }^{\wedge}\right.$ the product of] the Mediation between them; $\left[^{\wedge}\right.$ from which having the $\{\wedge$ product $\}$ whieh $\{\wedge$ the $\}$ process is repeated and again $\{\wedge$ over $\&$ again $\}$ \{written in right margin: $\&$ so goes on without end.\}] In his "Introduction to the Philosophy of History," this is illustrated in the portion on "History as a Manifestation of Spirit"

\section{p. 451 Prose Writers}

[page break: the next page consists of two pasted fragments]

He has read my Vistas to little purpose who has not seen that the Democracy I favor [^ (if forced to choose,)] teaves [^ ${ }^{\wedge}$ willingly leaves yields all] all its material and political tri successes only to enter upon [^ \& enjoy] its true fild felds fietds [^ flights?] the moral, philosophical \& religious ones.

\section{[fragment break]}

I have [^ passingly] mentioned Hegel in the preceding pages, but I find [?] I shall $[\wedge$ cannot be] contented $[\wedge$ without saying something more elaborate about him, \& what he stands for.

If I were asked to point out [^ specify] who, ${ }^{\wedge}$ in my opinion, $]$ has $[\wedge$ by the operation of his individual mind] done the greatest most signal service to humanity, so far, [^ I sometimes think] my answer would be [^ out of all history] to point to [^ $\mathrm{him}]$ no less a person than the German teacher $[\wedge \&$ metaphysieian, Frederiek) Heget - and perhaps join with him [^ his name] the names of Kant, $[\wedge$ and perhaps] Fichte, \& Schelling. ${ }^{\wedge}$-the F?] If I were questioned to mention who [^ ${ }^{\wedge}$ most fully \& definitely] illustrates my ideas of Democracy [^ ${ }^{\wedge}$ by carrying it into the highest regions,] I should make the same answer.

[page break: the next page consists of two pasted fragments]

There is a close [^ relative-] connection, sequence \&c. between all the four great Ger= man philosophers even in time. (They fit into each other like a nest of boxes-and Hegel encloses them all.

\section{[fragment break]}

Taking th their [^ whole] philosophy, [?] as a it is the most important emanation of the mind of modern ages, $[\wedge$ and of all ages, ] leaving all [^ even] the

[page break: the next page consists of three pasted fragments]

\section{Idealism underlies the for}

Four great philosophers, all alike. It does not crop to the surface in Kant, but he necessitates it more than any of them. 
Transcendentalism

[fragment break]

-is the $[\wedge$ not $]$ only $\left[\wedge\right.$ the] grand $\left[\wedge\right.$ est $\left[^{\wedge}\right.$ antedating background] \& appropriate entrance to the study of any science [^ but to] a the fit understanding of the position of one's self in Nature, $\left[\wedge\right.$ to] the performance of life's duties, or $[\wedge$ to $]$ the $\left[{ }^{\wedge}\right.$ appreciation and] application of sane standards to politics and to the [^ judgment upon and] construction of works in any department of Art,

[fragment break]

Idealism underlies the tom How r great philosophers. all w like. It does not crop to surface in. Kant, tat he nesenstates it more than ans of them.

Irancendentalizin

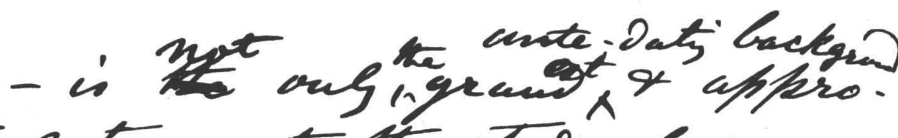
private tent entrance to the otis of any science the fit molerstangs of the portion of vies ref\% in talus the

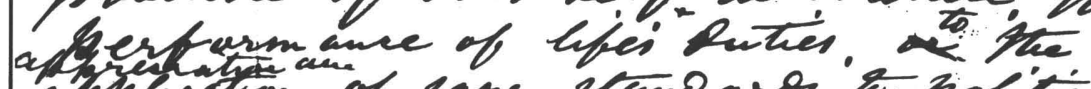

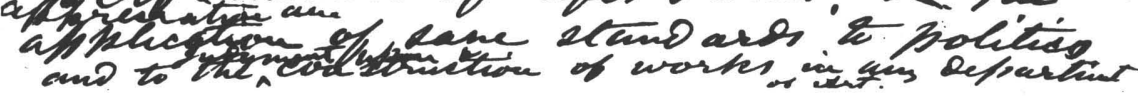

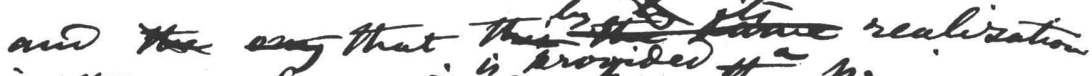

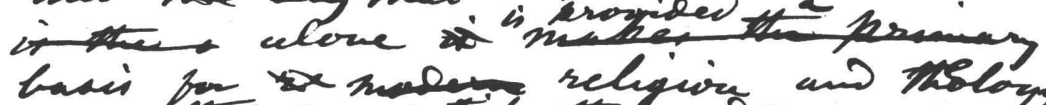

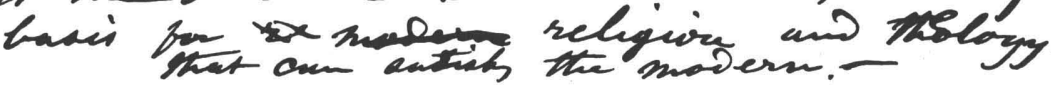

Manuscript fragments of Whitman's “Sunday Evening Lectures." Harry Ransom Humanities Research Center, The University of Texas at Austin.

132 
and the only that this the same [^ ${ }^{\wedge}$ by by its] realisation is the alone is [^ ${ }^{\wedge}$ is provided a] makes the primary basis for [?] modern religion and theology that can satisfy the modern.-

\section{[page break]}

These [^ then] are the “illustrious [^ ${ }^{\wedge}$ illustrious] [^ Divine Idealistic] four,[quotation marks crossed out] who have originated carried out, with epic succession and completeness, the great modern systems of critical and transcendental philosophy. The critical philosophy is represented by Kant, who begins \& ends it. It is the The [^ transcendental] rest are is begotten by rises out of it $\&$ and is founded upon it [^ the critical,] and could $[\wedge$ have] had no beginning or growth except fr? from its previous existence 